\title{
Quiet Book Media Development to Improve Ecosystem Material Learning Results in Class V Elementary School
}

\author{
A. Indra Nihlah Annashih ${ }^{1}$, Waspodo Tjipto Subroto ${ }^{2}$
}

\section{ARTICLE INFO}

Article History:

Received 23.12.2018

Received in revised form

08.03.2019

Accepted

Available online 01.07.2019

\begin{abstract}
The objective of this study is to find out (1) Quiet Book media development procedures (2) Feasibility of developing Quiet Book media. This ty pe of research is Research and Development (R \& D) research, with a trial design of One Group Pretest-Posttest Design. A limited-scale trial was carried out on 5 VA class students and a large-scale trial was conducted on 25 VB grade students at the Elementary School in Wringinanom village. Data collection was conducted using questionnaires, observations, and tests . Questionnaires are used to obtain student response data, observations are employed to obtain learning implementation data, and tests used are to obtain learning outcomes data on cognitive aspects of students. The results showed that the developed media had been declared feasible by obtaining $92 \%$ validity percentage, $93 \%$ practicality of learning implementation, and effectiveness of student learning outcomes from pretest to posttest which is 75.04 to 93.52 , so that an average inc rease in scores of 18 was obtained. Effectiveness was also analyzed using $\mathrm{N}$-Gain with Gain value of 0.74 . So if it is interpreted in the Normalized Gain index table according to Hake, it is included in the High category $(0.70<\mathrm{g}<1.00)$. Thus, it c an be concluded that the development of Quiet Book media is declared feasible to be used as a learning media.
\end{abstract}

(C) IJERE. All rights reserved

Keywords:

Quiet Book Media, Learning Outcomes, Natural Sciences.

\section{INTRODUCTION}

The basic concepts in science are personal experiences that learners get by interacting with friends, teachers, nature and education systems that influence each other's basic conceptions of natural sciences in each individual student (Wisudawati, 2017: 8). So that natural sciences is considered as a science that is constructed personally and socially. To be able to touch the realm of meaningful learning of natural sciences, students need to pay attention to the process skills available in natural sciences. According to Suryanti (2013: 1), The skills of the natural sciences process expected at elementary school age are skills in observing, classifying, measuring, communicating, interpreting data, predicting, using tools, conducting experiments, and concluding. In the learning process, the teacher is also expected to be able to instill environmentally friendly attitude and love of nature as a manifestation of the application of the cognitive dimension of the field of natural sciences which can bring students into human beings who are wise in protecting nature.

To measure the achievement of learning, the teacher needs to conduct an evaluation. According to Suryanti (2013: 8), learning evaluation aims to determine the level of achievement of previously determined learning goals. Learning outcomes can be said to be successful if students experience changes in a positive direction, as in attitude, cognitive, and psychomotor aspects. Thus, the teacher needs to work on the conditions of learning that are memorable and enjoyable so that the learning outcomes can be better and the learning objectives can be achieved optimally.

In order to support natural sciences learning in elementary schools that is fun and has an impression on students, the teacher needs an intermediary that makes students able to translate abstract concepts through observation. According to Suryanti (2013: 5), observation is a process of obtaining information about an object by using sense devices. Intermediaries for teaching materials are learning media that are useful to make it easier for them to develop basic concepts in natural sciences materials. Media that is well used in elementary school children is the media closest to their environment and closest to the concrete objects they are studying. To maximize student learning outcomes and process skills, science learning in elementary schools requires media that is appropriate to the characteristics of elementary school age children.

Based on observations of researchers in state elementary school Wringinanom about the material of the ecosystem so far the media used are images, puzzles, and videos whereas images, puzzles, and videos have many limitations because they only involve the five senses in their use. The application of the media also

\footnotetext{
Corresponding e-mail:indra.17070855024@mhs.unesa.ac.id, orcid.org/0000-0001-9682-7886

${ }^{2}$ Corresponding e-mail: waspodosubroto@unesa.ac.id ${ }^{2}$ orcid.org/0000-0002-1477-1653
}

Posgraduate, Universitas Negeri Surabaya ${ }^{1}$, Senior Lecture, Universitas Negeri Surabaya ${ }^{2}$ 
feels less effective because it will only provide learning experiences in the cognitive domain which passes the results of natural sciences learning in elementary school in the aspects of process skills are not maximally achieved. So the media is needed to be able to balance the dimensions of attitude, cognitive and psychomotor by designing several activities in the media to encourage students to learn actively and pleasantly. One of the learning media that is suitable for honing the skills of observing and balancing learning experiences the attitude, cognitive and psychomotor dimensions of students, is Quiet Book (Mufliharsi:2017) . Quiet Book is a learning media made of flannel cloth that is cut to the size of a book . Inside there are activities that are useful to help students understand teaching material. Making Quiet Book does not require expensive fees, only requires teacher creativity in integrating activities with the material to be conveyed. In addition, activities in Quiet Book can be designed by teachers according to needs such as cutting, sticking, and buttoning what you can be used in groups to improve the ability of students to interact with peers.

Quiet Book is suitable for use in natural sciences learning because there are no standard rules about the content of the material. the teacher can easily connect some material that is considered suitable. Besides that according to Mufliharsi (2017), Quiet Book is suitable for use in natural sciences materials because its material is easily adapted to the needs of students both individually and in groups. The material that can be used in Quiet Book media is material that is not possible to be presented into the classroom and the teacher cannot bring students to the field to observe it.

The material which the researcher will use in this study is the material in class V Ecosystem. The results of research conducted by Risa Mufliharsi (2017) in the "Utilization of Quiet Book on Early Childhood Vocabulary in early childhood education programs" are the improvement in reading ability of children after learning with Quiet Book media. Whereas Quiet Book that will be developed by researchers is Quiet Book which is used for elementary students. The material used is adapted to the needs of elementary school students, namely Ecosystem material. In addition to supporting teaching material about the Ecosystem, the researchers modified Quiet Book by adding a bag of material that contains fragments of ecosystem material. Based on the concept of developing Quiet Book media in the material of class V Ecosystems, students are expected to be able to sharpen their observing and learning skills with a fun group. Material learning Ecosystems can be implemented by giving a meaningful impression on the memories of students. Through memorable learning, it can touch the realm of meaningful learning in the Ecosystem material to improve students' learning motivation. If this can be realized, it is hoped that learning will become a learning that can be well remembered by students and improve their learning outcomes in the dimensions of attitude, cognitive, and psychomotor.

\section{METHOD}

The type of research conducted by researchers is development research (Research and Development) or commonly abbreviated as R \& D. Sugiyono (2018: 297) defines R \& D is a research method used to produce certain products, and test the effectiveness of these products. The stages in this study were not carried out at the stage of mass production, but only arrived at the Quiet Book final. The procedure of development research used by researchers is a research procedure according to Sugiyono which can be described in the following chart:
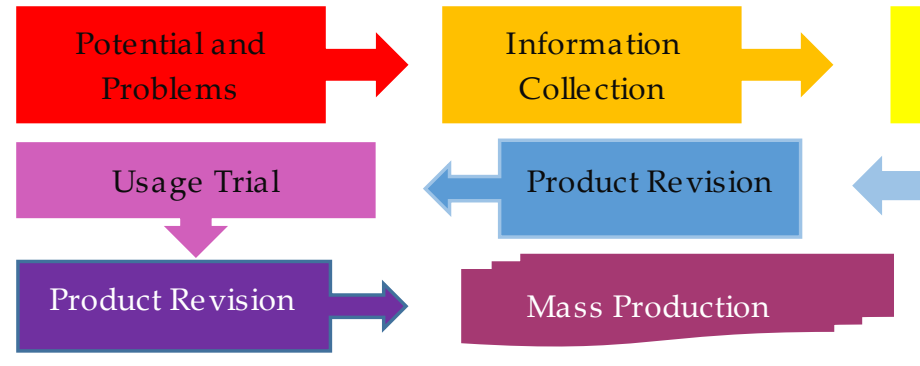

Figure 1. R\&D Research Procedure

This research was conducted at SDN Wringinanom, Gresik, East Java, Indonesia which was held in November 2018. The subjects of the trial in this study were all students from two classes namely VA and VB as the population in this study. This trial was carried out with the aim of perfecting the Quiet Book media by 
practicing it in Ecosystem material of natural sciences learning material in the class. In addition, the trial was conducted with the aim to find out the feasibility of Quiet Book media in learning, so researchers conducted an experiment before being treated the research subject $w$ as given a pretest problem and after being treated the research subject was given the posttest question. From treatment can be known more accurately because researchers can compare the state of the research subject before and after being treated.

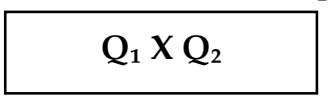

Information:

Q1 $=$ Pretest Value

Q2 = Posttest value

In this development research, the data obtained will be analyzed using inferential statistical analysis methods. Data analyzed by statistical tests are data derived from large-scale product trial activities. Largescale product testing is a trial for all students whose classes are not subject to limited scale testing. In a largescale product trial, the teacher carries out learning using Quiet Book media. During the learning process, the researcher observes the learning activities and is recorded on the observation sheet. Then, the researcher gave a questionnaire sheet that contained students' responses to learning by using the Quiet Book media that was being developed.

The type of data collected in this development research is quantitative data. This data is obtained from the results of student responses, the results of the students 'pretest scores, and the results of students' posttest scores. In this study, researchers used 3 data collection instruments, namely: Questionnaire Sheets, Observation Sheets, and Test Sheets. The instruments used to obtain the results of the feasibility of developing the Quiet Book Media are as follows: 1) the validity of Quiet Book includes presentation, ease of use and language. Media Quiet Book is said to be valid if the validation results are $>61 \%$. Learning Tool Validation is in category 3 (can be used with a little revision), or category 4 (can be used without revision). 2) practicality the use of Media Quiet Book is measured based on the implementation of learning (RPP) that has been made. Implementation is determined through an observation sheet filled in by the observer. The Quiet Media Book that was developed was declared practical if the percentage of learning outcomes was $>61 \%$. 3) effectiveness of the use of Quiet Book Media that is developed seen from student learning outcomes. The researcher treated the students by giving tests (pretest and posttest) to students. Quiet Book media development is declared effective if the $\mathrm{N}$-Gain test results have a result of $0.70<\mathrm{g}<1.00$ or in the High category.

\section{Data Analysis of Validation Results}

Data analysis of material expert assessment was analyzed using a likert scale.

$$
P(\%)=\frac{\text { number of scores from data collection }}{\text { maximum score }} \times 100 \%
$$

(Indarti, 2002:26)

\section{Data Analysis of Media Practical Quiet Book}

scores given by observers on teacher and student activities during learning a ccording to the following table.

\begin{tabular}{lc}
\hline Rating & Score \\
\hline Very Good & 4 \\
Good & 3 \\
Pretty Good & 2 \\
Not Good & 1 \\
\hline
\end{tabular}

The scores obtained are then calculated using the following formula:

$$
\mathrm{P}(\%)=\frac{f}{N} \times 100 \%
$$




\section{Analysis of the Effectiveness of Quiet Book Media}

The effectiveness of developing Quiet Book media can be seen from student learning outcomes obtained from the comparison of the values of the pretest and posttest. To determine the difference in the value of the pretest and posttest, it is necessary to calculate the value of N-Gain.

$$
\text { Normalized Gain }=\frac{\text { Posttest score }- \text { Pretest Score }}{\text { Maximum score }- \text { Pretest Score }}
$$

The values obtained are then interpreted in the Normalized Gain index table (g) according to the modified Hake.

Table 1. Normalized Gain Index (g) according to Hake

\begin{tabular}{cc}
\hline Normalized Gain Score & Interpretation \\
\hline$-1.00<\mathrm{g}<0.00$ & Decrease \\
$\mathrm{g}=0.00$ & Stable \\
$0.00<\mathrm{g}<0.030$ & Low \\
$0.30<\mathrm{g}<0.70$ & Average \\
$0.70<\mathrm{g}<1.00$ & High \\
\hline
\end{tabular}

\section{RESULT AND DISCUSSION RESULT}

In the early stages of analysis of potential and problems, curriculum analysis, student analysis and analysis of teaching material were carried out. The second stage collects data about the use of Quiet Book in the world of education, how to make Quiet Book, the advantages and disadvantages of Quiet Book media, and relevant research on the use of Quiet Book media in education bidders. The third stage of the design development of Quiet Book media is tailored to the needs of research based on the previous stage. The development of Quiet Book media consists of two important components, namely (a) Quiet Book Media; (b) Material Card. The Quiet Book media specifications are as follows: Rectangular, size $24 \mathrm{~cm} \times 34 \mathrm{~cm}$, made of flannel fabric, totaling 4 pages. While for material cards have the following specifications: A4 paper size, Comic Sands MS font type, and 12pt writing size. The flow of material designed by researchers on the first page describes the understanding of ecosystems and members of the rice field ecosystem. The second page, there are animal classification activities based on the type of food. On the third page is about individual organizations in ecosystems and interactions in ecosystems. and the last page, about activities to create a food chain in the ecosystem of rice fields.

After the media was designed, the research continued in the next stage, namely Quiet Book media validation. In this study, Quiet Book media will be validated by Yoyok Yermiandhoko, M.Pd. as validator 1, and Eva Yuli Astutik, S.Pd. as validator 2. Validation is done by filling out the questionnaire by each validator. The aspects assessed in the validation activities include: (1) Presentation of Media; (2) Ease of utilization; (3) Basic media. Based on the data obtained, the evaluation of the development of Quiet Book media on the presentation aspects of the media by validator 1 gets a percentage value of $80 \%$, the ease of use aspect gets a percentage value of $90 \%$, and linguistic aspects get a percentage value of $100 \%$. While the validator 2 gets a percentage value of $90 \%$, the ease of use aspect gets a percentage value of $100 \%$, and linguistic aspects get a percentage value of $90 \%$. The results of the Quiet Book media validation in detail can be seen in the following diagram:

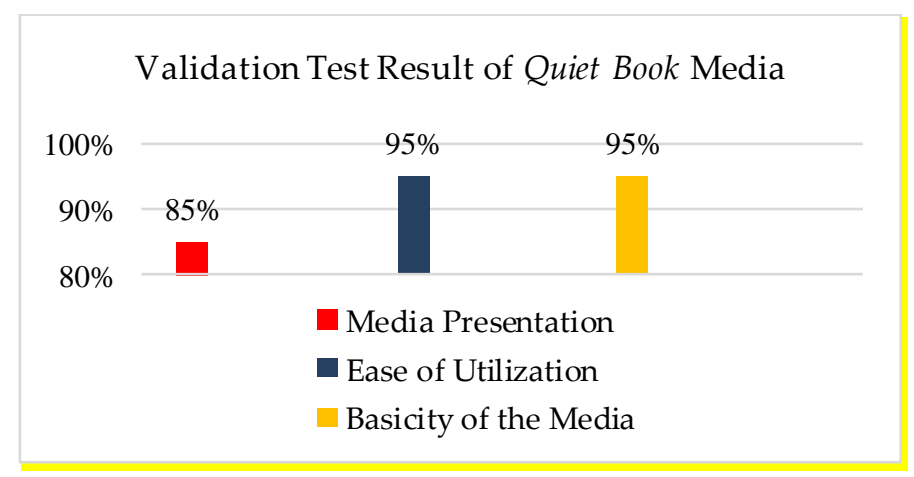


Figure 1. Quiet Book Validation Test Results

In the validation test there are 3 aspects assessed, namely the presentation of media, ease of use, and the basicity of the media. In the aspect of presentation, the media gets a score of $85 \%$. The ease of use of the media gets a score of $95 \%$. In the basic aspects, the media gets a value of $95 \%$. So that the total validity percentage obtained in the development of Quiet Book media is approximately $92 \%$. The percentage results are interpreted in a table that contains the criteria for the Quiet Book media validation test results. With the percentage of total validity and Quiet Book media, 92\% belongs to a very valid category $(81 \%-100 \%)$.

The second eligibility criteria for developing Quiet Book media is practical. The results of the practicality of the Quiet Book media in detail can be seen in the following diagram:

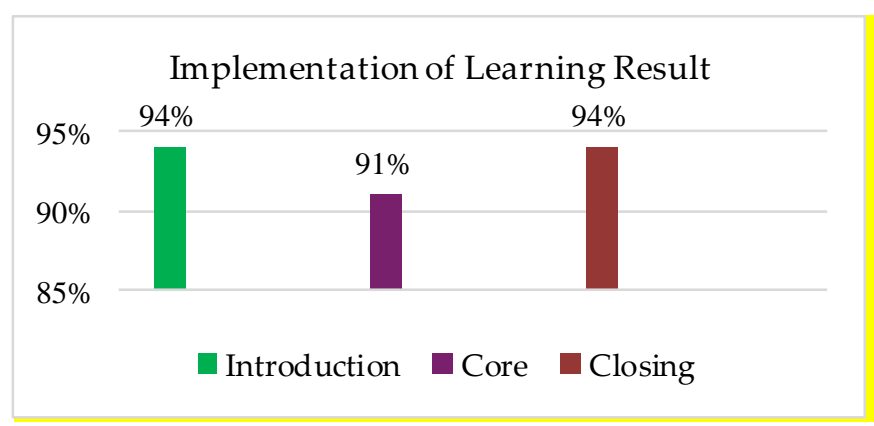

Figure 2. Learning Outcomes Results

As it has shown in figure 2 about the results of the implementation of learning, the initial activities get a percentage of $94 \%$, core activities $91 \%$, and closing activities at $94 \%$. So what if calculated on the average acquisition value of the implementation of learning obtained a percentage value of $93 \%$. Then, if the percentage of values interpreted in the criteria table, the percentage of practicality in Quiet Book media will be included in the excellent category (81\% -100\%). So it can be concluded that the Quiet Book media developed is a practical product.

The third eligibility criteria for developing Quiet Book media is effectiveness. The effectiveness of developing Quiet Book media can be seen from students' responses when testing is large scale. At the stage of a large-scale trial, the following data are obtained.

Table 2. Results of Student Response to Quiet Book media

\begin{tabular}{|c|c|c|c|c|c|c|c|c|}
\hline \multirow[b]{2}{*}{ No } & \multirow[b]{2}{*}{ Questions assessed } & \multicolumn{4}{|c|}{ Respon siswa } & \multirow[b]{2}{*}{ Respondents } & \multirow[b]{2}{*}{ Percentage } & \multirow{2}{*}{$\begin{array}{l}\text { Percentage } \\
\text { Criteria }\end{array}$} \\
\hline & & SS & $S$ & $\mathrm{R}$ & TS & & & \\
\hline \multirow[t]{2}{*}{1.} & The media used is presented in a & & & & & & & \\
\hline & $\begin{array}{l}\text { coherent manner so that I can easily } \\
\text { understand it. }\end{array}$ & 18 & 7 & & & 25 & $93 \%$ & Very good \\
\hline 2. & $\begin{array}{l}\text { The media used makes it easy for me to } \\
\text { learn. }\end{array}$ & 17 & 5 & 3 & & 25 & $89 \%$ & Very good \\
\hline 3. & $\begin{array}{l}\text { Images and activities in the Quiet Book } \\
\text { media are interesting to increase interest } \\
\text { in learning. }\end{array}$ & 20 & 5 & & & 25 & $95 \%$ & Very good \\
\hline 4. & I can read w ritings on Quiet Book easily. & 23 & 2 & & & 25 & $98 \%$ & Very good \\
\hline 5. & $\begin{array}{l}\text { I can easily understand the contents of } \\
\text { the material on Quiet Book. }\end{array}$ & 12 & 6 & 4 & 3 & 25 & $77 \%$ & Good \\
\hline 6. & $\begin{array}{l}\text { Language on material cards in Quiet } \\
\text { Book media can be easily understood. }\end{array}$ & 14 & 7 & 4 & & 25 & $85 \%$ & Very good \\
\hline 7. & $\begin{array}{l}\text { My knowledge increased after studying } \\
\text { using Quiet Book media. }\end{array}$ & 20 & 5 & & & 25 & $95 \%$ & Very good \\
\hline 8. & $\begin{array}{l}\text { Activities in the Quiet Book media not } \\
\text { only add to knowledge, but also exercise } \\
\text { patience, precision, and neatness in } \\
\text { carrying out it. }\end{array}$ & 17 & 5 & 3 & & 25 & $89 \%$ & Very good \\
\hline
\end{tabular}




\begin{tabular}{|c|c|c|c|c|c|c|c|c|}
\hline \multirow[b]{2}{*}{ No } & \multirow[b]{2}{*}{ Questions assessed } & \multicolumn{4}{|c|}{ Respon siswa } & \multirow[b]{2}{*}{ Respondents } & \multirow[b]{2}{*}{ Percentage } & \multirow{2}{*}{$\begin{array}{c}\text { Percentage } \\
\text { Criteria }\end{array}$} \\
\hline & & SS & S & $\mathrm{R}$ & TS & & & \\
\hline 9. & $\begin{array}{l}\text { After learning by using Quiet Book } \\
\text { media I understand the notion of } \\
\text { ecosystems, various ecosystems, } \\
\text { classification of animals based on their } \\
\text { food types, interactions that exist in } \\
\text { ecosystems, and food chains in } \\
\text { ecosystems. }\end{array}$ & 14 & 5 & 3 & 3 & 25 & $80 \%$ & Good \\
\hline 10. & I became more active in learning. & 16 & 5 & 4 & & 25 & $87 \%$ & Very good \\
\hline \multicolumn{2}{|c|}{ Average overall value of student responses } & & & & & $88.8 \%$ & & Very good \\
\hline
\end{tabular}

Based on table 2 about the results of student responses to Quiet Book media obtained a percentage value of $88.8 \%$, which when interpreted on the percentage criteria validation of students' viewpoints on Quiet Book media is included in the excellent category $(81 \%-100 \%)$, besides that students stated that the use of Quiet Book media as a learning media was very enjoyable. So that it can be infered that students' responses about Quiet Book media developed gets a positive response. Then, Quiet Book media is considered effective if it is able to improve student learning outcomes. This can be known by comparing the results of the pretest and posttest of students who previously the pretest and posttest questions have been validated.

Table 3. Pretest and posttest analysis

\begin{tabular}{|c|c|c|c|c|c|}
\hline No & $\begin{array}{l}\text { Student } \\
\text { Code }\end{array}$ & $\begin{array}{l}\text { Pretest } \\
\text { Score }\end{array}$ & $\begin{array}{l}\text { Posttest } \\
\text { Score }\end{array}$ & N-Gain & $\begin{array}{c}\text {-Gain } \\
\text { Interpretation }\end{array}$ \\
\hline 1 & MHM & 82 & 94 & 0.66 & Average \\
\hline 2 & NJC & 76 & 88 & 0.50 & Average \\
\hline 3 & NA & 64 & 94 & 0.83 & High \\
\hline 4 & RAP & 76 & 94 & 0.75 & High \\
\hline 5 & RNS & 82 & 88 & 0.33 & Average \\
\hline 6 & RA & 70 & 88 & 0.60 & Average \\
\hline 7 & RSA & 82 & 94 & 0.66 & Average \\
\hline 8 & RA. & 76 & 100 & 1 & High \\
\hline 9 & ANRA & 82 & 94 & 0.66 & Average \\
\hline 10 & ASR & 70 & 94 & 0.80 & High \\
\hline 11 & ADA & 70 & 94 & 0.80 & High \\
\hline 12 & $\mathrm{CDA}$ & 64 & 100 & 1 & High \\
\hline 13 & II & 76 & 94 & 0.75 & High \\
\hline 14 & $\mathrm{JN}$ & 76 & 94 & 0.75 & High \\
\hline 15 & MAF & 70 & 94 & 0.80 & High \\
\hline 16 & ML & 82 & 94 & 0.66 & Average \\
\hline 17 & $\mathrm{MF}$ & 82 & 94 & 0.66 & Average \\
\hline 18 & MMNA & 70 & 94 & 0.80 & High \\
\hline 19 & NPW & 76 & 94 & 0.75 & High \\
\hline 20 & NSA & 76 & 94 & 0.75 & High \\
\hline 21 & NFN & 82 & 94 & 0.66 & Average \\
\hline 22 & SLF & 76 & 94 & 0.75 & High \\
\hline 23 & VAI & 70 & 88 & 0.60 & Average \\
\hline 24 & CSA & 64 & 94 & 0.83 & High \\
\hline \multirow[t]{3}{*}{25} & BAMP & 82 & 94 & 0.66 & Average \\
\hline & Total & 1876 & 2338 & & \\
\hline & Average & 75.04 & 93.52 & 0.74 & High \\
\hline
\end{tabular}


Based on table3. Analysis of the pretest, posttest and N-Gain obtained data on the average results of the students' pretest is 75.04 and the average posttest results of students are 93.52 so that the average value of the pretest to posttest is 18.48 which can be rounded up to 18.5 points. Then, from the results of the pretest to posttest obtained the normalized Gain value was calculated using Microsoft Excel 2016 with an N-Gain average of 0.74 . If the N-Gain results are interpreted in the table of Normalized Gain Index (g) according to Hake

Tabel 4. Frequency of N-Gain

\begin{tabular}{lcc}
\hline Normalized Gain Score & Interpretation & Frekuensi \\
$-1.00<\mathrm{g}<0.00$ & Decrease & 0 \\
$\mathrm{~g}=0.00$ & Stable & 0 \\
$0.00<\mathrm{g}<0.30$ & Low & 0 \\
$0.30<\mathrm{g}<0.70$ & Average & 11 \\
$0.70<\mathrm{g}<1.00$ & High & 14 \\
$\quad$ Jumlah & & 25
\end{tabular}

Based on table 4 N-Gain results are interpreted in the table of Normalized Gain Index (g) according to Hake, it is included in the High category $(0.70<\mathrm{g}<1.00)$. Thus, it can be infered that the development of Quiet Book media effective because the development of students in learning using Quiet Book media is in the high category.

\section{DISCUSSION}

The discussion outlined includes an explanation of the feasibility of the developed Quiet Book media. The eligibility criteria for developing Quiet Book media used in this study are the criteria proposed by Sugiyono (2016: 216). The eligibility criteria for developing Quiet Book media include: (1) Validity (2) Practicality and (3) Effectiveness.

The developed media is said to be valid by experts because the percentage of Quiet Book media validation results in a validation percentage of $92 \%$, which if interpreted in the percentage criteria table for Quiet Book media validation falls into the very valid category $(81 \%-100 \%)$. In addition to the assessment on Quiet Book media that $w$ as developed, the validator also provided general assessment. One validator argues that the general assessment of Quiet Book media is included in category 3 (feasible to use with a slight revision) and one other validator stated that the general assessment of the Quiet Book media developed was included in category 4 (feasible to use without revision). The developed Media Quiet Book was stated to be practical because the percentage of implementation of learning using Quiet Book media reached 93\% if interpreted in the percentage criteria table validates the student's point of view then included in the excellent category. Then, Quiet Book media was declared effective because of an increase in students' cognitive learning outcomes which were known from the average value of the pretest and posttest. Based on the data obtained, the average increase in the value of the pretest to posttest is 18.5 points. Furthermore, the effectiveness of using Quiet Book media developed is also determined by the results of the N-Gain test.

The first eligibility criteria for developing Quiet Book media are valid. Validation is done by 2 validators. Validation is done by filling out the questionnaire by each validator. The aspects assessed in the validation activities include: (1) Presentation of Media; (2) Ease of utilization; (3) Basic media. Based on the data obtained, the evaluation of the development of Quiet Book media on the presentation aspects of the media by validator 1 gets a percentage value of $80 \%$, the ease of use aspect gets a percentage value of $90 \%$, and linguistic aspects get a percentage value of $100 \%$. In addition to evaluating percentages, the validator also provides general assessment. Validator 1 states that the general assessment of the development of Quiet Book media is included in category 3 (feasible to use with a slight revision). Furthermore, evaluation of the development of Quiet Book media on the presentation aspects of the media by validator 2 gets a percentage value of $90 \%$, the ease of use aspect gets a percentage value of $100 \%$, and linguistic aspects get a percentage value of $90 \%$. In addition to evaluating percentages, the validator also provides general assessment. Validator 2 states that the general assessment of the development of Quiet Book media is included in category 4 (feasible to use without revision). 
The second eligibility criterion for developing Quiet Book media is practical. Determination of validity and practicality is carried out by experts or people who understand well about learning devices. The practicality of developing Quiet Book media is also seen based on the implementation of learning. To find out the implementation of learning by using Quiet Book media developed can be done by observing the activities of the teacher. Observation of teacher activities is carried out by 2 observers, namely teachers and colleagues. Observations are carried out thoroughly including the initial / preliminary activities, core activities and closing activities. In the preliminary activity there were 4 activities, there were 7 core activities, and the closing activities were 2 activities. Based on data from diagram 2 about the results of the implementation of learning, the initial activities get a percentage value of $94 \%$, core activities at $91 \%$, and closing activities by $94 \%$. So what if calculated on the average acquisition value of the implem entation of learning obtained a percentage value of $93 \%$. Then, if the percentage of values interpreted in the criteria table, the percentage of practicality in Quiet Book media will be included in the excellent category $(81 \%$ $100 \%$ ). So it can be concluded that the Quiet Book media developed is a practical product.

The third eligibility criteria for developing Quiet Book media is effectiveness. The effectiveness of developing Quiet Book media can be seen from students' responses when testing is large scale. At the largescale trial stage there were no difficulties in using Quiet Book media. Based on table 2. about the results of student responses to Quiet Book media obtained a percentage value of $88.8 \%$, which when interpreted on the percentage criteria validation of students' viewpoints on Quiet Book media is included in the excellent category $(81 \%-100 \%)$, besides that students stated that the use of Quiet Book media as a learning media was very enjoyable. So that it can be concluded that students' responses about Quiet Book media developed are positive responses. Then Quiet Book media is considered effective if it is able to improve student learning outcomes. This can be known by comparing the results of the pretest and posttest of students who previously the pretest and posttest questions have been validated. Based on table 3. Analysis of the pretest, posttest and N-Gain obtained data on the average results of the students' pretest is 75.04 and the average posttest results of students are 93.52 so that the average value of the pretest to posttest is 18.48 can be rounded up to 18 points. Based on the results of the pretest to posttest, $\mathrm{N}$-Gain values were calculated using Microsoft Excel 2016, not obtained by students with the N-Gain test results in the Decrease category $(-1.00<\mathrm{g}$ $<0.00)$, Stable $(\mathrm{g}=0.00)$, and Low $(0.00<\mathrm{g}<0.30)$. Then, 11 students were in the Average category $(0.30<\mathrm{g}$ $<0.70)$, and 14 students were in the High category $(0.70<\mathrm{g}<1.00)$. Besides that, in the development of Quiet Book media, the average value of the N-Gain Test was 0.74 which, if interpreted in the table of Normalized Gain Index (g) according to Hake, was included in the High category $(0.70<\mathrm{g}<1.00)$. This shows that the use of Quiet Book media developed has the effect of positive changes in student learning outcomes. Thus it can be infered that the development of Quiet Book media will be effective because the development of students in learning using Quiet Book media is in the high category.

Thus, based on: (1) Bloom's theory in Sapriati (2009: 1.12) which suggests that the age of 7-11 years or elementary school level is a concrete operational stage, where at this stage, children begin to show changes in thinking from the less logical to more logical. So that some concepts that are still difficult for students to understand need to be realized in learning media that can reduce the possibility of misconceptions in the material. Then, according to Rohman (2016: 163) learning media has Manipulative functions meaning learning media can be used to overcome the boundaries of space and time and human sensory limitations in learning a teaching material. The psychological basis of reason or rational use of learning media in terms of student conditions and how the learning process occurs (Rohman, 2016: 136). So researchers are interested in developing Quiet Book media used for ecosystem material for grade V elementary school students. Based on the results of the feasibility test for developing Quiet Book media that includes validity, practicality and effectiveness of the developed media, it can be infered that the development of Quiet Book media is declared feasible used as a learning media.

\section{CONCLUSION}

Based on the results of the research and discussion of the results of the study using Quiet Book Media which was developed, it has met the research and development (R \& D) research procedures according to Sugiyono, which was carried out in nine stages without continuing the mass production stage. The eligibility criteria for developing Quiet media include 3 things, including: (1) Validity; (2) Practicality; (3) Effectiveness. The developed media is said to be valid by experts because the percentage of Quiet Book media validation 
results in a validation percentage of $92 \%$, which if interpreted in the percentage criteria table for Quiet Book media validation falls into the very valid category $(81 \%-100 \%)$. The developed Quiet Book Media was stated to be practical because the percentage of the implementation of learning using Quiet Book media reached $93.52 \%$, which if interpreted in the percentage criteria table of validation of the student's point of view was included in the excellent category. Then Quiet Book media was declared effective because of an increase in students' cognitive learning outcomes which were known from the average pretest value of 75 to 93 at posttest, so that it can be seen that learning outcomes experienced an average increase of 18 points. Then from the results of the pretest to posttest the Normalized Gain value was obtained using Microsoft Excel 2016 with the N-Gain value of 0.74 . If the results of the N-Gain analysis are interpreted in the table of Normalized Gain Index (g) according to Hake it is included in the High category $(0.70<\mathrm{g}<1.00)$. Thus, it can be concluded that the development of Quiet Book media is declared feasible to be used as a learning media to improve ecosystem material study results in Class V of Elementary School. Based on the research that has been done, it is suggested that teachers should always play an active role in improving student learning outcomes by trying their best to develop methods or media used to support learning so learning becomes enjoyable so that it can touch the realm of meaningful learning and this research can be used as a foundation for researchers then in order to be better developed to improve the quality of education in Indonesia.

\section{REFERENCES}

Indarti, T. (2002). Penelitian Tindakan Kelas dan Penulisan Ilmiah. Surabaya: FBS Unesa.

Kunandar (2015). Penilaian Autentik.Jakarta: PT RajaGrafindo Perkasa.

Mufliharsi, R. (2017). Pemanfaatan Busy Book Pada Kosakata Anak Usia Dini Di Paud Swadaya Pkk. Jurnal Penelitian Pendidikan Guru Anak Usia Dini. Vol.5(146-155).

Nilmayani (2017). Pengaruh Penggunaan Media Busy Book Terhadap Kemampuan Membaca Permulaan Pada Anak Usia 5-6 Tahun Di Paud Terpadu Filosofia Kubu Babussalam Rokan Hilir. Pendidikan Guru Pendidikan Anak Usia Dini Fakultas Keguruan Dan Ilmu Pendidikan Universitas Riau.

Sudjana, N. (2011). Penilaian Hasil Belajar Mengajar.Bandung: Remaja Rosdakarya.

Sugiyono (2016). Metode Penelitian Pengembangan Research and Development. Bandung:Alfabeta.

Sugiyono (2018). Metode Penelitian Kuantitatif, Kualitatif, dan RED. Bandung: Alfabeta.

Suryanti, dkk. (2013). Pengembangan Pembelajaran IPA SD. Unesa University Press.

Sutrisno, L. A. P. (2017). Pengembangan LKS Berbasis RBL Untuk Meningkatkan Hasil Belajar Siswa Kelas V. Jurnal Penelitian Pendidikan Sekolah Dasar.

Ulfah, A. A. (2017). Pembuatan Dan Pemanfaatan Busy Book Dalam Mempercepat Kemampuan Membaca Untuk Anak Usia Dini Di Paud Budi Luhur Padang: Jurnal Ilmu Informasi Perpustakaan dan Kearsipan. Vol. (6), 28-37.

Wakhyudin (2014). Efektifitas Model Think Pair Share Dalam Pembelajaran Tematik Integratif Terhadap Kemampuan Pemecahan Masalah". Universitas Negeri Semarang. Vol 1.

Winarsunu, T. (2015). Statistik dalam Penelitian Psikologi dan Pendidikan. Penerbitan Universitas Muhammadiyah Malang.

Wisudawati, A W. (2017). Metodologi Pembelajaran IPA. Jakarta: PT Bumi Aksara. 